American Journal of Applied Sciences 6 (6): 1246-1254, 2009

ISSN 1546-9239

(C) 2009 Science Publications

\title{
Competitiveness and Prospects of Greek Asparagus: The European Context
}

\author{
${ }^{1}$ Argyrios D. Kolokontes and ${ }^{2}$ Anastasios Semos \\ ${ }^{1}$ Technological Education Institute of Western Macedonia, Department of Agricultural Products, \\ Marketing and Quality Control, Faculty of Agriculture, Florina, 53100, Greece \\ ${ }^{2}$ Aristotle University of Thessaloniki, Department of Agricultural Economics, Faculty of Agriculture, \\ Thessaloniki, 54006, Greece
}

\begin{abstract}
Problem statement: The revisions and the anticipated abolition of CAP will change the agricultural structure in member states of EU. Although the asparagus, without government interventions, from the decade of 90' has been transformed at one of more promising, in exports terms, cultivation for Greece, however under the existing circumstances it has a doubtful future. Approach: This research studied the diachronic evolution of competitiveness of white fresh Greek asparagus into the European context. A scheme of trade indices, based on post-trade and post-production data, had been estimated in respect of absence from the literature of a single generally accepted measure of competitiveness. Results: The results demonstrated that the Greek asparagus presents both a highly dependency of the German market and a penetration weakness into other markets, except from the Dutch one. The lack of Greek large retail chains with considerable geographic dispersion in West Europe contributes to trading problem. The feeble domestic consumption in Greece in combination with the enlargement of German production and the implied diminishing of its imports, cause restlessness for the future of cultivation and the producers' income in Greece. Conclusion: A long term trading pattern for bonds creation in foreign supply channels and the growth of domestic consumption in Greece are indispensable to support and expand the future prospects of Greek asparagus.
\end{abstract}

Key words: Asparagus, net trade, bilateral trade, revealed comparative advantage

\section{INTRODUCTION}

The Common Agricultural Policy (CAP) of EU, with the governmental protectionist interventions is accountable for the structural distortions in agriculture $^{[1]}$. A consequence of CAP in Greek agriculture was the abandonment of actual traditional cultivations with effective superiority in favor of others. Over time, these "others" cultivations were baptized "traditional" and the government interventions directed and determined both the agricultural production and trade $^{[2]}$. The CAP's revisions, under the commitments from the negotiations in the context of WTO for the gradual liberalization of markets and trade, as well as the accession of new members with competitive agricultural activities in the $\mathrm{EU}^{[3,4]}$ have caused restlessness to growers for the future ${ }^{[5]}$ of "traditional" cultivations. "Alternatives or new" crops were promoted as solutions to confront the shrinkage of producers' prices and their incomes. The "alternatives" were transubstantiated in "concrete" cultivations just for a small number of cases ${ }^{[6]}$.
Although asparagus cultivation cannot be considered as a "new" one, due to the fact that set off its route in Greece from the decade of 60', however the product concentrated the growers' interest throughout the decade of 90' constituting a "healthy" outlet for the agricultural areas. On average from 1995-2003 the cultivated, with asparagus land, covered the $5.66 \%$ of the total of vegetables, with a peak at 8.037 ha approximately in $1998^{[7]}$. The contribution of value of exported asparagus in the formation of the Standard International Trade Classifications (SITC) categories, during the period 1996-2004, reached on average at $2.15 \%$ of the exports value of food and live animals (section 0 of SITC), at $1.42 \%$ of the exports value of agricultural products (sections $0,1,4$ of SITC) and at $0.35 \%$ of the total value of products and services that exported from the country ${ }^{[7,8]}$. Taking for granted the numerousness of existing economic activities, the number of agricultural or non-agricultural products and services that are produced and traded and the proportion of cultivated with asparagus land to the total arable land

Corresponding Author: Argyrios D. Kolokontes, TEI of Western Macedonia, Terma Kontopoulou-53 100 Florina-Greece Tel: +30-23850-54610 Fax: +30-23850-46630 
of Greece, the contribution of Greek asparagus exports in the formation of national exports is significant.

The asparagus, without government interventions, has been transformed at one of the more promising cultivations in exports terms for Greece. During the decade 1996-2005, in Greece was produced the $11.26 \%$ of EU's production, taking into consideration all the 27 members that the EU numbered in our days, with an average output at $4,095.04 \mathrm{~kg} \mathrm{ha}^{-1[9]}$.

This study is an empirical study based on posttrade and post-production data for the diachronic evolution of competitiveness ${ }^{[10,11]}$ of white fresh Greek asparagus and its prospects.

In the first session of the study methodology is presented. The following session refers to Greek asparagus within the European context. The third session composes the core empirical part with the results for the competitiveness of white fresh Greek asparagus and the last session constitutes a summary of conclusions.

\section{MATERIALS AND METHODS}

The study has been based on diachronic estimations for a scheme of trade indices in respect that, in the literature, there is no index with general acceptance to examine the competitiveness for a product $^{[1,12]}$. The statistical data comes from the Food and Agricultural Organization of the United Nations ${ }^{[9,13]}$ (FAO), the National Statistical Service of Greece $^{[7]}$ (NSSG) and the Panhellenic Exporters Association $^{[8]}$ (PEA).

The focus group consists of countries with a percentage of white asparagus at least $80 \%$ of their total annual production of the product or/and present significant trade flows of white fresh asparagus with Greece or/and belong to the main competitors for the Greek product. Particularly in Greece, this percentage share of white fresh asparagus to its total asparagus production reaches at $95 \%{ }^{[9,13-16]}$.

The estimated trade indices for the analysis are the exporting and importing penetration indices (EP, IP), the net trade index, a type Michaelly Index, a specialization of Revealed Symmetrical Comparative Advantage index (RSCA) and exporting prices indices.

The exporting and importing penetration indices (EP, IP) are estimated as:

$$
\begin{aligned}
& \text { E.P. }_{\cdot j}=X_{j} /\left(P_{j}+M_{j}\right) \\
& \text { I.P. }{ }_{j}=M_{j} /\left(\operatorname{Pr}_{j}+M_{j}-X_{j}\right)
\end{aligned}
$$

in which: $\operatorname{Pr}_{\mathrm{j}}$ is the asparagus production in country $\mathrm{j}$, $M_{j}$ and $X_{j}$ are the respective imports and exports, $\left(\operatorname{Pr}_{\mathrm{j}}+\right.$ $\mathrm{M}_{\mathrm{j}}$ ) is the total "illusive" supply in the domestic market of country $\mathrm{j}$ and $\left(\mathrm{Pr}_{\mathrm{j}}+\mathrm{M}_{\mathrm{j}}-\mathrm{X}_{\mathrm{j}}\right)$ is the respective domestic "illusive" demand. The sums $\left(\operatorname{Pr}_{\mathrm{j}}+\mathrm{M}_{\mathrm{j}}\right)$ and $\left(\mathrm{Pr}_{\mathrm{j}}+\mathrm{M}_{\mathrm{j}}-\mathrm{X}_{\mathrm{j}}\right)$ are characterized as domestic "illusive" supply and demand respectively, because they compose only estimates for the real magnitudes, e.g., includes the waste and the quantities that does not end up as fresh product abroad but as frozen or proceeding kind. However their use helps the estimation of EP and IP indices which reveal the countries with highly exporting orientation or with an important role as importers.

The methodology for the study of revealed comparative advantage was fastened by Balassa ${ }^{[5]}$. The concept is to distinguish the competitive products of a country in the international trade $\mathrm{e}^{[10,11,17,18]}$. In this paper three terms have been used ${ }^{[12]}$ : the net trade index ("Normalized Balassa") $\mathrm{NT}_{\mathrm{j}}$ for the study of consequences from the external asparagus trade on national trade balance $e^{[19,20]}$, a specialization of Michaelly index ${ }^{[21,22]}$ for bilateral ${ }^{[23,24]}$ analysis $\mathrm{BM}_{\mathrm{GR} \leftrightarrow \mathrm{j}}$ and a specialization of revealed symmetrical comparative advantage index ${ }^{[4,21,25]}$ for study of tripartite competitiveness-penetration relations $\operatorname{TRSCA}_{[\mathrm{GR}(\mathrm{Vs}) \mathrm{j}] \rightarrow \mathrm{k}}$ regarding one of the three participated countries as a common target market for the other two. These indices have been derived from the following equations:

$$
\begin{aligned}
& \mathrm{NT}_{\mathrm{j}}=\left(\mathrm{X}_{\mathrm{j}}-\mathrm{M}_{\mathrm{j}}\right) /\left(\mathrm{X}_{\mathrm{j}}+\mathrm{M}_{\mathrm{j}}\right), \mathrm{NT}_{\mathrm{j}} \in[-1,1] \\
& \mathrm{BM}_{\mathrm{GR} \leftrightarrow \mathrm{k}}=\left(\mathrm{X}_{\mathrm{GR} \rightarrow \mathrm{k}} / \mathrm{TX}_{\mathrm{GR}}\right)-\left(\mathrm{M}_{\mathrm{k} \rightarrow \mathrm{GR}} / \mathrm{TM}_{\mathrm{GR}}\right) \\
& \mathrm{BM}_{\mathrm{GR} \rightarrow \mathrm{j}} \in[-1,1] \\
& \operatorname{TRSCA}_{[\mathrm{GR}(\mathrm{V} s) \mathrm{j}] \rightarrow \mathrm{k}}=\left(\operatorname{TRCA}_{[G R(V s) j] \rightarrow k}-1\right) / \\
&\left(\operatorname{TRCA}_{[G R(V s) j] \rightarrow k}+1\right), \\
& \operatorname{TRSCA} \in[-1,1]
\end{aligned}
$$

with a specialization of TRCA as:

$$
\begin{aligned}
\mathrm{TRCA}_{[\mathrm{GR}(\mathrm{Vs}) \mathrm{j}] \rightarrow \mathrm{k}}= & \left(\mathrm{X}_{\mathrm{GR} \rightarrow \mathrm{k}} / \mathrm{TX}_{\mathrm{GR}}\right) /\left(\mathrm{X}_{\mathrm{j} \rightarrow \mathrm{k}} / \mathrm{TX}_{\mathrm{j}}\right), \\
& \mathrm{TRCA} \in[0,+\infty)
\end{aligned}
$$

In which: $\mathrm{X}_{\mathrm{GR} \rightarrow \mathrm{k}}$ indicates the annual exports of Greek asparagus to country $\mathrm{k}$ and $\mathrm{TX}_{\mathrm{GR}}$ the total annual exports of Greek asparagus worldwide, $\mathrm{M}_{\mathrm{k} \rightarrow \mathrm{GR}}$ is the annual asparagus imports in Greece from country $\mathrm{k}$ and $\mathrm{TX}_{\mathrm{GR}}$ the total annual asparagus imports in Greece from abroad, $\left(\mathrm{X}_{\mathrm{GR} \rightarrow \mathrm{k}} / \mathrm{TX}_{\mathrm{GR}}\right)$ indicates the share of Greek 
asparagus in market $\mathrm{k}$ and $\left(\mathrm{X}_{\mathrm{j} \rightarrow \mathrm{k}} / \mathrm{TX}_{\mathrm{j}}\right)$ country's $\mathrm{j}$ asparagus share in market $\mathrm{k}$ and $\operatorname{TRCA}_{[\mathrm{GR}(\mathrm{V}) \mathrm{j}] \rightarrow \mathrm{k}}$ is the tripartite revealed comparative (dis)advantage of Greek asparagus in comparison to the product of country $\mathrm{j}$ into a common target market $\mathrm{k}$.

If $\mathrm{NT}_{\mathrm{j}}=0$, then the imports value of the product are equal with its exports value and the product neither improve nor surcharge the trade balance of the country. If $\mathrm{NT}_{\mathrm{j}} \rightarrow+1$, then the product improves the trade balance and presents highly exporting orientation and vice versa when $\mathrm{NT}_{\mathrm{j}} \rightarrow-1$.

The $\mathrm{BM}_{\mathrm{GR} \leftrightarrow \mathrm{j}}$ and $\mathrm{TRSCA}_{[\mathrm{GR}(\mathrm{Vs}) \mathrm{j}] \rightarrow \mathrm{k}}$ indices fluctuate in the same range with the $\mathrm{NT}_{\mathrm{j}}$ index. Both these indices take into consideration the relevant trading size of each country, using either quotients of exports to a target market $k$ or quotients of imports from a country $j$ in relation to the respective worldwide trading flows of compared countries. The first is specialized to study the bilateral trade ${ }^{[23,24]}$, with Greece as benchmark of comparisons, comparing the proportion between the Greek asparagus exports to the country $\mathrm{k}$ with the respective imports of this country in order to ascertain bilateral competitive (dis)advantages. The latter is specialized with the target market as comparator and compares the export shares of two countries (Greece as benchmark and country j) into a common target market $\mathrm{k}$ in order to determine the comparative (dis)advantage of Greek asparagus in this market within of a tripartite relation.

Although, the $\mathrm{NT}_{\mathrm{j}}$ index is estimated from values data due to the fact that the trade balance are affected both from the volume and the value of imports and exports, however the estimations of $\mathrm{BM}_{\mathrm{GR} \leftrightarrow \mathrm{j}}$ has been based on quantities data owing to the both exports and imports usage so that the values does not affect on the bilateral (dis)advantage. As far as the index of $\operatorname{TRSCA}_{[G R(V s) j] \rightarrow k}$ is concerned, which is defined exclusively by exports, its estimations were based on value of data taking into consideration the price influence ${ }^{[26]}$.

The price indices were estimated as the quotient between the total annual value of asparagus exports from a country $\mathrm{j}$ and the respective annual exported quantity. The price indices reveal the annual average price of exports from country $\mathrm{j}$ to country $\mathrm{k}$.

The Greek asparagus into the European context: The asparagus plants, during the period of 1995-2003, has been corresponded to $5.66 \%$ of cultivated with vegetables land of Greece, with a peak of 8,037 ha approximately in $1998^{[7]}$. The asparagus production in Greece has been rising until year 2001 (31,000 tones) and then, presented a loss of about 9.5 thousand tones until year 2006 which implied a falling tendency (below the average) to its contribution in the formation of SITC categories.

During the period of 1996-2005 over than $99.22 \%$ (which is the smallest percentage in 2000) of exported Greek asparagus ended up to destinations in EU-27 ${ }^{[13]}$. The bulk of exported Greek asparagus follows the traditional route for many Greek agricultural products to the market of Munich. In the decade of 1996-2005, on average $84.2 \%$ of Greek asparagus exports has been absorbed by the German market, only with small annual fluctuations. Although, in 1996, the apportionment of exported Greek asparagus was similar among the Dutch, France and Spain markets (2.38, 2.36 and $2.05 \%$, respectively), diachronic the concentration has been enlarged only to the Dutch market ${ }^{[13]}$. An increasingly exporting percentage to the Netherlands was recorded with annual percentages to be bigger (between 7.58 and $13.43 \%$ ) than the decade average $(7.57 \%)$ after year $2000^{[13]}$. The exports to France were restricted both as quantities and proportion and was considerably decreased from 1999 (8.50)-2005 (1.90\%), while, after year 1999 (except from the year 2003) the share of exports to the Spanish market dropped below from the unit ${ }^{[13]}$.

The great dependency of Greek asparagus from the German market does not leave alternative choices and this is a risk for the future of cultivation in Greece and for the producers' income. It must be pointed out that the imports of Germany, in the period of 1996-2005 were diminished 17.979 tones, $-42.1 \%{ }^{[9]}$. At the moment, Greek exports sets out an outlet only to the Dutch market, but a satisfactory penetration into new markets in foreseeable future is indispensable. The increase of asparagus production in Germany has already conduced at the diminution of Greek asparagus production. After year 2003, an attempt to find new markets for the Greek asparagus has been focused on new members (CEEC) of EU-27 ${ }^{[4,27]}$ but it remains weak, $6.11 \%$ in $2005^{[13]}$, owing to the structural restrictions of Greek supply chains and the lack of suitable coordination with foreign partnerships ${ }^{[26]}$.

The diachronic evolution of exporting and importing penetration indices (EP, IP) in Table 1 indicates high exporting orientation for the Greek, Dutch and Spanish asparagus. In the case of Greece, on average, $66.5 \%$ of estimating domestic supply was sold abroad and this measurement was considerably bigger rather than the corresponding averages for the other 
Am. J. Applied Sci., 6 (6): 1246-1254, 2009

Table 1: Diachronic evolution of EP and IP Indices of asparagus per Country

\begin{tabular}{|c|c|c|c|c|c|c|c|c|c|c|c|}
\hline \multirow{2}{*}{\multicolumn{12}{|c|}{$1996(\%) \quad 1997(\%) \quad 1998(\%) \quad 1999(\%) \quad 2000(\%) \quad 2001(\%) \quad 2002(\%) \quad 2003(\%)$}} \\
\hline & & & & & & & & & & & \\
\hline Greece & 94.8 & 71.3 & 82.8 & 78.7 & 54.7 & 62.3 & 80.1 & 38.5 & 58.1 & 43.6 & 66.5 \\
\hline Netherlands & 53.6 & 38.9 & 32.0 & 39.3 & 36.4 & 27.3 & 34.9 & 28.2 & 30.7 & 33.3 & 35.5 \\
\hline Spain & 22.7 & 34.8 & 32.2 & 29.8 & 29.6 & 37.7 & 33.0 & 28.3 & 30.9 & 28.8 & 30.8 \\
\hline France & 14.8 & 17.2 & 14.2 & 13.2 & 15.5 & 18.8 & 17.8 & 19.4 & 14.0 & 13.4 & 15.8 \\
\hline $\begin{array}{l}\text { Germany } \\
\text { IP: }\end{array}$ & 0.5 & 0.7 & 0.8 & 1.6 & 0.9 & 2.8 & 1.6 & 1.3 & 1.2 & 1.4 & 1.3 \\
\hline Greece & 9.1 & 1.0 & 2.7 & 5.0 & 0.4 & 0.2 & 0.6 & 1.0 & 6.6 & 6.2 & 3.3 \\
\hline Netherlands & 36.5 & 46.4 & 32.5 & 54.0 & 31.7 & 33.7 & 51.1 & 45.2 & 45.4 & 47.3 & 42.4 \\
\hline Spain & 3.1 & 6.3 & 6.2 & 7.6 & 8.0 & 8.7 & 10.2 & 14.3 & 14.9 & 22.8 & 10.2 \\
\hline France & 26.5 & 33.0 & 32.9 & 29.3 & 43.3 & 49.4 & 54.2 & 47.7 & 49.2 & 43.7 & 40.9 \\
\hline Germany & 54.1 & 49.5 & 48.6 & 47.8 & 38.0 & 42.0 & 34.4 & 31.3 & 26.7 & 23.3 & 39.6 \\
\hline
\end{tabular}

Note: Authors' Calculations ${ }^{1,2}$

countries, 35.5 and $30.8 \%$ for the Netherlands and Spain respectively. An explanation is that the asparagus, until the end of the previous decade, was not yet included in the nourishment habits of Greek consumers. The dependency of exported Greek asparagus from the German market (especially in the case that the Greek producers have not achieved earliness) in combination with the increase of relevant German production have caused the stabilization's absence for the EP index of Greece.

France which was a traditional exporter in the decade of 60', the continually decrease of its production had as a result the fall of its E.P. index to low levels. For the period in question, although the production of France was diminished $-37.3 \%$, its E.P. index had a relevant short fluctuation range (from 19.4-13.2\%) with an average at $15.8 \%$ and this means that the proportion between exports and estimating domestic supply has been kept at similar levels due to the faster increase of French imports in order to cover the domestic consumption. The fast increase of French imports was recorded from the IP index which was fluctuated between 26.5 and $33 \%$ in the period of 1996-1999 but, after year 2000, its annual percentages were over than $43.3 \%$.

The IP index was high, on average $42.4 \%$, for the Netherlands as well. The difference between Netherlands and France is that the first had a remarkable steady domestic production in all these years. Both high levels of the exporting and importing penetration indices for the Netherlands create the impression that the country performs a "middleman" role for the trade of white fresh asparagus in West Europe.

A particular interest present the increasingly trend of IP index of Spain, from 3.1 in 1996 to $22.8 \%$ in 2005 with a similar rationalization as in the case of France and a loss of Spanish asparagus production at $38.6 \%$ in the studied time series.

Greece presents the lower IP index, on average $3.3 \%$, due to the fact that the domestic production overcomes the low, in comparison with the other countries, domestic consumption and permits the rising fluctuation of its exports without significant effects on its imports.

Germany, which is one of the big importers and producers of white fresh asparagus worldwide, in 2006 became the biggest asparagus producer in EU-27 with a percentage $32.1 \%$ (Spain 18.7, Italy 16.7, Greece 8.5, France 7.5, the Netherlands 5.9, Bulgaria 5.9, Others $4.7 \%$ ). Germany, on average for the period of 19962005 , exported only $1.3 \%$ of its estimating domestic supply and imported almost $2 / 5$ of the corresponding estimating domestic demand, owing to the insufficiency of German production to satisfy the domestic consumption. The difference between France and Germany was that the I.P. index for the later was decreasing and its average was bigger than the annual estimations after year 2001. The average conceals a significant alteration, from 1996, when Germany had to import more than half of its domestic consumption, to 2005 when its imports were restricted at 1/4 of estimating domestic consumption. The intense fall of IP index of Germany elucidates the unsteadiness and the annual reductions of Greek EP index because of Greece's vital dependency from the German asparagus marketplace. However, Germany continues to be unable to cover the consumers' requirements and confronts earliness difficulty.

\section{RESULTS AND DISCUSSION}

Figure 1 depicts the evolution of Net Trade (NT) index for the studied countries. Greece, Spain and the Netherlands have positive rates. France reveals negative rates after year 1998 and Germany for all the period.

In the case of Germany, the petty improvement of the NT index (Fig. 1) is consorted with the increase of its production and the fall of IP index (Table 1). The high domestic consumption in connection with the low EP index of Germany (Table 1) prevented the further improvement for country's NT index and loaded to an almost absolute disadvantage from the asparagus external trade for the German trade balance. 


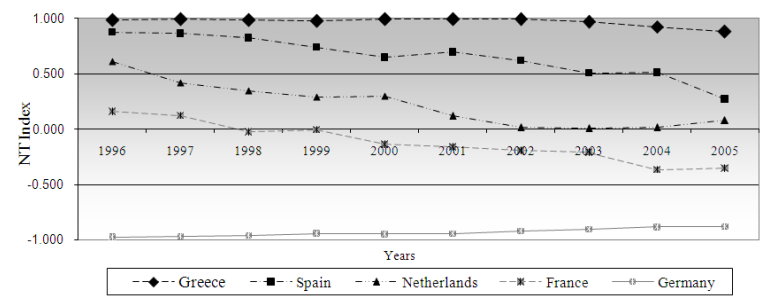

Fig.1: Diachronic evolution of asparagus NT Index Per Country ${ }^{[13]}$

Specifically, the index has been estimated near to -1 for all the years of time series with an average -0.934 that indicates the surcharge of trade balance of Germany.

The NT index of France corroborates the view that the role of France for the asparagus trade has been modified from exporter to importer. The surcharge of French trade balance has been enlarged from 1998 (-0.025)-2005 (-0.355) and the average for the NT index was -0.118 due to the positive rates of 1996 and 1997.

In the same period the benefits for the Dutch trade balance from the asparagus trade was vanished. The NT index from 0.612 in 1996 had tumbled down to 0.005 in 2003 (Fig. 1). After year 2002, the index fluctuated between 0.015 and 0.077 (Fig. 1). Under the repercussion that the Netherlands has undertaken a "middleman's" role in West Europe (Table 1) in asparagus external trade, after the year 2002 this role has secured employment positions for the country without giving benefits to its balance.

Spain and Greece remain the only countries of the group which continue to enjoy such benefits from the asparagus external trade. Taking the relevant stability of EP index of Spain for granted, the falling of its NT index can be interpreted through the hurling of IP index (Table 1). The NT index of Spain recorded a decrease equal to $-69.3 \%$ from $1996(+0.875)$ to 2005 $(+0.269)$, whereas the average $(+0.655)$ was bigger than the annual rates after the year 2001.

The Greek trade balance obtains more benefits from the asparagus external trade than the Spanish one. The small volume of imports in combination with the high exporting orientation of Greek asparagus (Table 1) provide to Greece an almost absolute advantage for its balance as it seems from the rates of NT index of Greece which was close to +1 for all the years of the studied period with an average at +0.971 (Fig. 1). The falling of the NT index after year 2002 is correlated with the falling of the Greek EP index (Table 1).

The Table 2 shows the results of BM index. Although Greece has more benefits than Spain from the asparagus external trade (Fig. 1), from the focus on their bipartite trading relation is ascertained that none of them success a competitive advantage, as it is proven from the annual rates of BM index. Except from the year 1999 in which the index was negative (affecting the average), for all the other years from 1996-2005 the rates are almost zero (Table 2).

Greece had presented competitive disadvantage in the bilateral trade with the Netherlands until year 2003 and only after that, reversed this situation owing to the increase of its export share into the Dutch market. An interpretation of the negative rates, especially in the period of 2000-2003 (Table 2), is the consequences of the geographic dispersion of large foreign retailing chains, taking into account the Greek market. The extension of Dutch-German and French retailing chains functioned in favor of the asparagus imports from the Netherlands and France. As a repercussion, despite the decrease of French production, the Greek asparagus gained no advantage from the bilateral trade with France (Table 2). On the contrary the decrease of Greek exports to the French market created a disadvantage after year 2002 in terms of bilateral trade. The parallel between Greece and French indicates the trade problem for the Greek product due to the lack of Greek large retailing chains with considerable geographic dispersion in West Europe ${ }^{[28,26]}$.

Greece maintains a bilateral trading advantage visà-vis to Germany (Table 2). The gathering of Greek asparagus in German market can be justified from the distributional and promotional activities of great Greek colony. The earliness of Greek product in comparison with the German constitutes one more reason.

Table 3 shows the results of tripartite specialized index of revealed symmetrical comparative advantage (TRSCA). Under the apportionment criterion of exported Greek asparagus, marketplaces of Germany, France and Holland used as the set of the target markets. The Swiss market, as the most important market for the Greek asparagus exports which is outside the EU-27, has been added into the group. Each one of the above target markets have been used as a comparator in order to estimate the comparative (dis)advantage of Greek asparagus (which is the benchmark) in a specific target market in comparison with their competitors. The direct parallel of competing countries, regarding their exporting shares in each target market in comparison to their worldwide exports, has taken into consideration the relevant size among the competitors. Price indices in Table 4 have been estimated to fortify the results.

Greek asparagus had an advantage in German market where it presented its bigger gathering. Concretely, from the comparison between the Greek and the French product, the average of TRSCA index 
Am. J. Applied Sci., 6 (6): 1246-1254, 2009

Table 2: Diachronic evolution of BM index, with Greece as benchmark of comparisons

\begin{tabular}{lrrrrrrrrrrr}
\hline Diachronic evolution & 1996 & \multicolumn{1}{c}{1997} & 1998 & 1999 & \multicolumn{1}{c}{2000} & 2001 & 2002 & 2003 & 2004 & 2005 & Average \\
\hline Greece-Germany & 0.745 & 0.247 & -0.001 & 0.383 & 0.205 & 0.845 & 0.795 & 0.800 & 0.777 & 0.763 & 0.556 \\
Greece-France & -0.705 & -0.267 & 0.049 & 0.085 & 0.070 & 0.033 & 0.037 & -0.070 & -0.408 & -0.295 & -0.147 \\
Greece-Spain & 0.020 & 0.059 & 0.001 & -0.192 & 0.032 & 0.001 & 0.007 & 0.021 & 0.002 & 0.003 & -0.004 \\
Greece-Netherlands & -0.046 & -0.030 & -0.054 & -0.058 & -0.257 & -0.695 & -0.533 & -0.122 & 0.022 & 0.050 & -0.172 \\
\hline
\end{tabular}

Note: Authors' calculations ${ }^{[13]}$

Table 3: Diachronic evolution of TRSCA index with Greek asparagus as benchmark and its main European target markets as comparators

\begin{tabular}{llllllllllll}
\hline Diachronic evolution & 1996 & 1997 & 1998 & 1999 & 2000 & 2001 & 2002 & 2003 & 2004 & 2005 & Average \\
\hline German market: & & & & & & & & & & & \\
Greece-Spain & 0.374 & 0.334 & 0.451 & 0.374 & 0.417 & 0.443 & 0.396 & 0.397 & 0.422 & 0.393 & 0.400 \\
Greece-France & 0.365 & 0.340 & 0.420 & 0.344 & 0.452 & 0.441 & 0.694 & 0.655 & 0.771 & 0.786 & 0.527 \\
Greece-Netherlands & 0.057 & 0.026 & 0.057 & 0.047 & 0.080 & 0.108 & 0.234 & 0.252 & 0.308 & 0.384 & 0.155 \\
French Market & & & & & & & & & & & \\
Greece-Spain & -0.909 & -0.857 & -0.797 & -0.718 & -0.807 & -0.913 & -0.892 & -0.867 & -0.897 & -0.940 & -0.860 \\
Greece-Germany & -0.427 & -0.268 & -0.080 & -0.385 & -0.156 & -0.796 & -0.693 & -0.850 & -0.728 & -0.811 & -0.519 \\
Greece-Netherlands & -0.002 & -0.266 & 0.213 & 0.440 & 0.303 & -0.300 & -0.596 & -0.488 & -0.446 & -0.760 & -0.190 \\
Dutch market: & & & & & & & & & & & \\
Greece-Germany & -0.860 & -0.484 & -0.010 & -0.803 & -0.381 & -0.422 & -0.428 & 0.358 & -0.011 & -0.294 & -0.334 \\
Greece-Spain & -0.539 & 0.292 & -0.292 & -0.022 & 0.599 & 0.772 & 0.802 & 0.821 & 0.847 & 0.705 & 0.398 \\
Greece-France & 0.552 & 0.767 & 0.465 & 0.364 & 0.490 & 0.482 & 0.765 & 0.894 & 0.859 & 0.809 & 0.645 \\
Swiss market: & & & & & & & & & & & \\
Greece-Spain & -1.000 & -0.986 & -0.996 & -0.956 & -0.680 & -0.035 & 0.540 & -0.794 & 0.611 & -0.019 & -0.432 \\
Greece-France & -1.000 & -0.999 & -0.999 & -0.992 & -0.952 & -0.848 & -0.951 & -0.985 & -0.948 & -0.982 & -0.966 \\
Greece-Netherlands & -1.000 & -0.950 & -0.979 & -0.825 & -0.439 & 0.197 & -0.597 & -0.906 & -0.572 & -0.771 & -0.684 \\
Greece-Germany & -1.000 & -0.997 & -0.999 & -0.978 & -0.896 & -0.579 & -0.674 & -0.960 & -0.868 & -0.944 & -0.890 \\
\hline
\end{tabular}

Note: Authors' calculations ${ }^{[13]}$

Table 4: Diachronic evolution of annual average prices of exported asparagus per target market $(\$ / \mathrm{kg})$

\begin{tabular}{|c|c|c|c|c|c|c|c|c|c|c|c|}
\hline Diachronic evolution & 1996 & 1997 & 1998 & 1999 & 2000 & 2001 & 2002 & 2003 & 2004 & 2005 & Average \\
\hline \multicolumn{12}{|l|}{ German market: } \\
\hline Greece & 2.321 & 2.367 & 2.140 & 1.819 & 2.111 & 2.251 & 2.091 & 2.509 & 2.343 & 3.020 & 2.297 \\
\hline Spain & 4.104 & 3.460 & 3.516 & 3.451 & 2.796 & 2.777 & 2.864 & 3.537 & 4.141 & 3.849 & 3.449 \\
\hline France & 5.482 & 4.492 & 4.645 & 3.951 & 4.134 & 3.553 & 3.296 & 4.934 & 5.724 & 5.103 & 4.531 \\
\hline Netherlands & 4.220 & 4.611 & 4.212 & 3.657 & 3.480 & 3.813 & 2.883 & 4.030 & 4.383 & 4.147 & 3.944 \\
\hline \multicolumn{12}{|l|}{ French market: } \\
\hline Greece & 1.072 & 1.383 & 1.464 & 0.949 & 1.077 & 1.094 & 1.324 & 1.498 & 2.007 & 1.774 & 1.364 \\
\hline Spain & 3.288 & 2.764 & 3.030 & 2.809 & 2.158 & 1.983 & 2.249 & 2.968 & 3.714 & 3.423 & 2.839 \\
\hline Germany & 4.167 & 4.333 & 1.750 & 1.046 & 1.871 & --- & 2.247 & 2.493 & 2.806 & 2.874 & 2.621 \\
\hline Netherlands & 4.352 & 3.720 & 3.068 & 3.122 & 2.355 & 2.044 & 2.145 & 2.832 & 2.906 & 2.594 & 2.914 \\
\hline \multicolumn{12}{|l|}{ Dutch Market } \\
\hline Greece & 2.203 & 2.103 & 2.195 & 1.442 & 1.766 & 1.681 & 1.667 & 1.700 & 2.810 & 2.465 & 2.003 \\
\hline Germany & 3.561 & 1.950 & 1.443 & 1.997 & 1.720 & 2.020 & 1.820 & 2.903 & 2.726 & 3.170 & 2.331 \\
\hline Spain & 4.852 & 3.592 & 3.869 & 4.073 & 2.552 & 2.413 & 2.364 & 3.315 & 3.483 & 4.383 & 3.490 \\
\hline France & 1.794 & 2.611 & 3.266 & 2.767 & 2.883 & 2.603 & 3.031 & 3.548 & 4.105 & 4.525 & 3.113 \\
\hline \multicolumn{12}{|l|}{ Swiss market: } \\
\hline Greece & --- & --- & --- & 2.103 & 2.581 & 3.081 & 3.436 & 4.316 & 4.290 & 3.737 & 3.363 \\
\hline Spain & 1.972 & 1.268 & 1.312 & 1.155 & 1.091 & 1.066 & 0.936 & 3.393 & 2.448 & 1.753 & 1.639 \\
\hline France & 5.861 & 4.828 & 4.739 & 4.302 & 3.808 & 2.851 & 3.418 & 4.726 & 4.896 & 4.789 & 4.422 \\
\hline Netherlands & 5.461 & 5.368 & 3.848 & 4.419 & 3.556 & 4.128 & 3.696 & 4.465 & 4.524 & 4.549 & 4.401 \\
\hline Germany & 5.143 & 3.825 & 3.171 & 3.886 & 2.874 & 3.394 & 3.835 & 4.210 & 4.395 & 4.225 & 3.896 \\
\hline
\end{tabular}

Note: Authors' calculations ${ }^{[13]}$

was 0.527 with positive annual rates for all studied years and annual rates bigger than the average after the year 2001 (Table 3). Comparing the Greek with the Spanish product the average was 0.400 with positive annual rates and relevant stability for the whole of the studied period, whereas in the case of Greek vis-à-vis to Dutch product the average was 0.155 smaller than the annual rates after year 2001 (Table 3).
Greek asparagus seems to have a steady diachronic comparative advantage in comparison with the Spanish one and improves its position in comparison with the French and Dutch products (Table 3). Taking into consideration the fact that the exporting quantities of white fresh asparagus to German market has been diminished for the studied countries for granted, most likely seems that the penetration of Greek asparagus 
into the marketplace of Germany is more durable than the relevant of its competitors (especially from those of the Netherlands and France). The average of annual average prices of exported Greek asparagus in period 1996-2005, $2.279 \$ / \mathrm{kg}$ (smaller than the measurements after the year 2002), have diachronic been kept at more competitive levels than the relevant prices of exported Spanish, French and Dutch asparagus to Germany (3.349, 4.531 and $3.944 \$ / \mathrm{kg}$, respectively). The lower labor cost of Greek production and the trading of the Greek homogeny in Germany have played their part in this, permitted satisfactory incomes for the Greek producers as well. On the contrary, the diminution of German imports due to the growth of German production has hit seriously the imports from the Netherlands and France which were being presented the bigger averages in terms of annual averages prices.

Greek asparagus, concluding from the estimations of TRSCA index (Table 3), have not succeeded competitive penetration in France, where the Greek product has been at a disadvantage compared to the Spanish, German and Dutch products (except for the triennium 1998-2000 in the case of the comparison with the Netherlands) notwithstanding its lower prices (Table 4). A potential explanation for the price of Greek product in connection with its poor penetration in French market can be considered, the almost exclusive conveyance of precocious Greek asparagus to Germany, with a consequence that the French market has been considered as a supplementary target market from the Greek exporters. This means that the Greek exporters turn to French market in the period when cultivated the bulk of asparagus production in Germany while the French crop has not been sufficient.

Although in the bilateral trade with the Netherlands, the BM index reveals a disadvantage for Greece until 2003 (Table 2), however into the Dutch market the Greek asparagus have gained comparative advantage in comparison with the French (all the period 1996-2005) and Spanish (after the year 2000) products (Table 3). After year 2000, the increasing absorbability of Greek asparagus in Dutch market has consolidated its comparative advantage. In the same market the Greek product had a disadvantage compared to the German asparagus (average: -0.334), with a small improvement after year 2002. The annual average price of exported Greek asparagus to the Dutch market has been recorded lower than the corresponding price to the German market (expect from the years 1998 and 2004) and higher than the corresponding price to the French market (Table 4). This observation is in deal with the manner that the Greek exporters look at the target markets of Germany and France, as well as deal with the moving of a part of Greek exports from German to Dutch market after year 2000. As concerns the comparison among the Greek price and the competitors' prices, the Greek product has been absorbed in Dutch market at higher prices than the Spanish and French asparagus (Table 4).

Switzerland is the most important importer among the non-EU countries. The Swiss market imports similar quantities of white and green fresh asparagus. The French-speaking and the German-speaking part of the country are traditionally provided with French and German white fresh asparagus. The TRSCA index (Table 3) shows that the Greek asparagus possessed a comparative disadvantage in the Swiss marketplace visà-vis to French, German and Dutch products (averages: $-0.966,-0.890$ and -0.684 , respectively). For the couple of Greek and Spanish asparagus has not observed an advantage for any of these products. The exported Greek asparagus in Swiss market recorded higher average annual prices than the rest markets under study (Table 4), but the price of Greek product compared with the averages annual prices of German, French and Dutch asparagus (except for years 2001 and 2002 for the case of French product) was lower.

\section{CONCLUSION}

The empirical results end up that Greek asparagus take an advantage of its competitors only in German market and it cannot achieve a satisfactory penetration into other markets, except for the Dutch one. Spain and Greece are the only competitors among the European countries with significant quantities of production and exports that continue to gain benefits at their trade balance. The problem of exporting dispersion of Greek asparagus does not come from an advantage of Spanish product. The weak penetration in other markets except for that of Germany and the Netherlands cannot be considered as quality weakness for the Greek asparagus and it is interpreted as a problem at the channels of trade. The advantage of Greek asparagus in the German marketplace has been connected with the distributional and promotional activities of Greek colony and reveals the weakness of Greek exporters to create trading chains in other markets on abroad where does not exists Greek homogeny. The lack of Greek large retailing chains with considerable geographic dispersion in West Europe contributes to the trading problem ${ }^{[28,26]}$.

The dependency of Greek exports from Germany is anticipated to cause negative consequences (some of them have already recorded) in asparagus production of Greece, while the production of Germany will be enlarged and its imports will be diminished. The Greek 
asparagus must maintain and improve its earliness and quality in order to maintain the penetration in the German market. The improvement of earliness of Greek asparagus can secure its exports not only in Germany but in other markets as well.

High quality, the freshness, perfect standardization and the competitive earliness must be the differentiation agents ${ }^{[29]}$ for the Greek asparagus. The brand names of the exported quantities must indicate its origin ${ }^{[29]}$. The Greek asparagus needs trading connections that will improve its penetration abroad to more markets and will contribute to gain its independency from the German one, creating alternative choices ${ }^{[26]}$.

A significant disadvantage for the asparagus cultivation in Greece is the lack of a strong domestic consumption base that exposes the producers if their production cannot be exported. The external trade of asparagus creates benefits for the Greek trade balance but this is a macroeconomic benefit which must not be confused with the microeconomic benefit of securing a satisfactory income for the Greek producer. The trade balance of Germany is being surcharged from the asparagus external trade in macro terms, but the independent German producer from the changes of foreign markets will understand that with high certainty the sale of his/her production to the domestic German market will obtain more security from the Greek producer in micro terms. The further promotion of asparagus in Greek market and its inclusion into the Greek nourishment ${ }^{[29]}$ constitutes one more key-agent for the future of the cultivation in Greece particularly after the awaited abolition of CAP.

The above observations can incite a discussion for further study in order to adopt a long term trading pattern $^{[4]}$ that will improve and expand the future prospects for the Greek asparagus.

\section{REFERENCES}

1. Fertö, I. and L.J. Hubbard, 2003. Revealed comparative advantage and competitiveness in hungarian agri-food sectors. World Econ., 26: 247-259. DOI: 10.1111/1467-9701.00519

2. Wesley, E., F. Peterson and S.R.K. Valluru, 2000. Agricultural comparative advantage and government policy interventions. J. Agric. Econ., 51: $\quad 371-387 . \quad$ DOI: $\quad 10.1111 /$ j.14779552.2000.tb01237.x

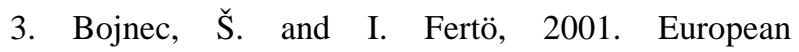
enlargement and agro-food trade. Can. J. Agric. Econ., 56: 563-579. DOI: 10.1111/j.17447976.2008.00148.x
4. Bojnec, Š. and I. Fertö, 2008. Agro-food trade sustainability in central and Eastern Europe. Int. J. Sustainable Econ., 1: 100-112. DOI: 10.1504/IJSE.2008.020019

5. Balassa, B., 1965. Trade liberalization and "revealed" comparative advantage. Manchester School, 33: 99-123. DOI: 10.1111/j.14679957.1965.tb00050.x

6. Gavruchenko, T., G. Baltas, F. Chatzitheodoridis and S. Hadjidakis, 2003. Comparative marketing strategies for organic olive oil: The case of Greece and Holland. Cahier Options Méditerranéennes, 61: 247-255.

http://ressources.ciheam.org/om/pdf/c61/00800167.pdf

7. National Statistical Service of Greece, N.S.S.G., 1999-2007. Agricultural Statistics of Greece for the Years 1995-2003, Annual Bilingual (EnglishGreek) Editions of N.S.S.G, Athens. Also available (in Greek) at: http://www.statistics.gr/anaz.asp

8. Panhellenic Exporters Association, P.E.A., 2006. Statistical Series of Greek Exports: 1945-2005. Athens, Special Bilingual (English-Greek) Edition for the Sixty Birthdays of P.E.A. Export Research Centre. PEA's. http://www.pse.gr/eng/main.htm

9. Faostat, F.A.O., 2008a. ProdSTAT [on line]. Food and agriculture organization of the United Nations. http://faostat.fao.org/site/567/default.aspx\#ancor

10. Ballance, H.R., H. Forstner and T. Murray, 1987. Consistency tests of alternative measures of comparative advantage. Rev. Econ. Stat., 69: 161-161. http://www.jstor.org/pss/1937916

11. Amador, J., S. Cabral and J. Ramos-Maria, 2007. Export specialization over the last four decades: How does portugal compare with other cohesion countries? Econ. Bull. Banco De Portugal, 13: 145-159.

12. Iapadre, L., 2003. A taxonomy of statistical indicators for the analysis of international trade and production. Proceedings of the 4th International Trade Statistics Expert Meeting, Apr. 7-9, Paris, France. http://www.oecd.org/document/41/0,3343,en_2649 34241_2498857_1_1_1_1,00.html

13. Faostat, F.A.O., 2008b. TradeSTAT [on line]. Food and agriculture organization of the United Nations. http://faostat.fao.org/site/535/default.aspx

14. Nigh, L.E.Jr., 1999. The explosion of new asparagus production worldwide and what it means. Proceedings of the ISHS Acta Horticulturae 479: IX International Asparagus Symposium, Pasco, Washington, USA., pp: 11-15. http://www.actahort.org./books/479/479_0.htm

15. Nichols, A.M., 2002. Year-round asparagus production. In: ISHS Acta Horticulturae 589: X International Asparagus Symposium, Proceedings, Niigata, Japan, pp: 29-32. http://www.actahort.org./books/589/589_2.htm 
16. Benson, L.B., 2002. Update of the world's asparagus production areas, spear utilization and production periods. Proceedings of the ISHS Acta Horticulturae 589: X International Asparagus Symposium, Niigata, Japan, pp: 33-40. http://www.actahort.org./books/589/589_3.htm

17. Hinloopen, J. and C. van Marrewijk, 2001. On the empirical distribution of the balassa index. Rev. World Econ., (Weltwirtschaftliches Arch.), 137: 1-35. DOI: 10.1007/BF02707598

18. Havrila, I. and P. Gunawardana, 2003. Analyzing comparative advantage and competitiveness: An application to Australia's textile and clothing industries. Aust. Econ. Paper, 42: 103-117. DOI: 10.1111/1467-8454.00189

19. Webster, A. and M. Gilroy, 1995. Labour skills and the UK's comparative advantage with its European union partners. Applied Econ., 27: 327-342. DOI: 10.1080/00036849500000117

20. Tung, A.C., 2003. Beyond flying geese: The expansion of East Asia's electronics trade. German Econ. Rev., 4: 35-51. DOI: 10.1111/14680475.00072

21. Laursen, K., 1998. Revealed comparative advantage and the alternatives as measures of international specialization. Danish Research Unit for Industrial Dynamics (DRUID-Research Program), Working Paper no. 98-30, Copenhagen, IVS, Copenhagen Business http://ideas.repec.org/p/aal/abbswp/98-30.html

22. Daskapan, S., 2008. The reliability of trade performance indicators in the new e-economy. The Changing Structure of the Telecommunications Industry and the New Role for Regulation, eProceedings of 17th Conference of International Telecommunications Society, Montreal, Quebec, Canada. http://www.canavents.com/its2008/
23. Wu, Y. and Z. Zhou, 2006. Changing bilateral trade between China and India. J. Asian Econ., 17: 509-518. DOI: 10.1016/j.asieco.2006.04.007

24. Zhou, Z.Y., Y.R. Wu and W. Si, 2007. Evolving patterns of agricultural trade between Australia and China. Aus. Agribus. Rev., 15: 27-45. http://www.agrifood.info/review/2007/Zhou_Wu_ Si.html

25. Dalum, B., K. Laursen and G. Villumsen, 1998. Structural change in OECD export specialization patterns: de-specialization and "stickiness". Int. Rev. Applied Econ., 12: 423-443. DOI: 10.1080/02692179800000017

26. Mashabela, T.E. and N. Vink, 2008. Competitive performance of global deciduous fruit supply chains: South Africa Versus Chile. Agrekon, 47: 240-257. http://econpapers.repec.org/article/agsagreko/37632.htm

27. Gorton, M. and S. Davidova, 2001. The international competitiveness of CEEC agriculture. World Econ., 24: 185-200. DOI: 10.1111/14679701.00351

28. Vlachos, P.I. and P.G. Patsis, 2004. Exports of Greek fresh produce to UK: An analysis of the barriers to and the conditions for successful export performance. Agric. Econ. Rev., 5: 36-46. http://ideas.repec.org/a/ags/aergaa/26407.html

29. Theodossiou, G. and C. Kourti, 2007. Marketing research merely reflects the needs and wants of consumers. Am. J. Applied Sci., 4: 587-591. http://www.scipub.org/fulltext/ajas/ajas48587591.pdf 